\title{
HELICAL PILE BEHAVIOUR ANALYSIS IN DIFFERENT SOILS
}

\author{
SKRŪVPĀḶA DARBĪBAS ANALĪZE DAŽĀDĀS GRUNTĪS
}

\author{
A.Sprince, L.Pakrastinsh
}

Keywords: helical pile, screw pile, soils, compression, displacement, finite element method

\section{INTRODUCTION}

There is variety of choices how to use the pile foundations in construction. They are used in cases when the top layers of soil basics are weak and better soils deposits relatively deep [1]. The most often one can find piles of reinforced concrete, timber and steel, hollow-shell pile of concrete and reinforced concrete, replacement and drilled piles, but more rarely helical piles [2]. As to physical properties in many occasions deposit weak soils and frequently the non equal settlement of building bases is to be found what costs the deformation of the building, cracks in structures and decorations, then helical screw piles are a good way how to strengthen new and already existing basements.

The earliest known use of a helical screw pile foundation was for the support of lighthouses in tidal basins around England. An English brick maker, Alexander Mitchell, is credited with design of a "screw pile" for this purpose in 1833 [3]. Helical piles are ground anchors constructed of helical-shaped circular plates welded to steel circular or square shaft at a specified spacing. Figure 1 shows a typical configuration for a multi helix screw pile in compression [4].

During loading, the force applied to the pile is transferred to the surrounding soil. Thus, the ultimate capacity of the pile is dependant upon the strength of the soil. Soils derive their strength and ultimate load capacity from several characteristics like the internal friction angle $\varphi$, the adhesion factor $\alpha$, the volume weight $\gamma$ and the undrained shear strength of the soil [6]. The depth of the screw piles setting up is limited by density of soil as well as economical and practical obstacles. The piles are screwed in the ground using either truck mounted or excavator with special rotary head and soil composition are damaged minimally [4].

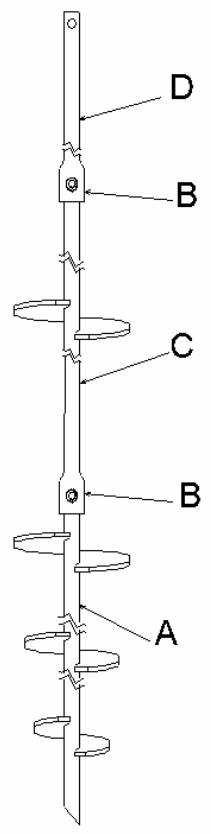

Helical piles have more than one essential advantages comparing to other piles: they can be screwed in with handy equipment, it is important in places, where one can not get close with heavy technology, for example, in basements, under the bridges etc.; the installation of a screw pile foundation is for practical purposes vibration free. These features make the screw pile foundation attractive on sites that are environmentally sensitive. Installations near existing foundations or footings generally cause no problems and they can be used repeatedly. They also have some disadvantages: load limitations because of possible carrying capacity of handle, there is a possible corrosive in unfavorable soil conditions.

There are several calculation methods of screw piles load carrying capacity: Latvian building code LBN 214-03 “Geotechnics. The basics and foundations of piles” [2] or СНиП 2.02-03-85 „Pile foundation"[8], "A.B.CHANCE" company calculation method [4] and Canadian building engineer developed large capacity screw piles calculation methods $[5,6]$. If we look at all three helical piles calculation methods, conclusions are very different and hard to compare in between themselves. 
Latvian building code LBN 214-03 or СНиП 2.02-03-85 is assigned for screw piles with one capacitive plate, however "A.B.CHANCE" company calculation method and Canadian building engineer developed large capacity screw piles calculation methods are used for the calculation of screw piles capacity with one or several capacitive plates. Nevertheless, the behaviour model of screw piles in each of the method is different.

\section{CALCULATION METHODS}

\subsection{The ultimate compression capacity of the helical pile according to Latvian building code}

Theory suggests that the capacity of a foundation pile is equal to the capacity of helice and design strength of soil on the shaft end. The helice capacity is determined by calculating the unit bearing capacity of the soil and applying it to the helice area. The ultimate compression capacity $F_{d}$ of the helical pile, with helix diameter $\mathrm{d} \leq 1.2 \mathrm{~m}$ and length $1 \leq 10 \mathrm{~m}$, see Equation (1).

$$
F_{d}=\gamma_{c}\left[\left(\alpha_{1} c_{I}+\alpha_{2} \gamma_{I} h_{1}\right) A+u f_{i}(h-d)\right]
$$

where $F_{d}$ - pile compression capacity [kN]; $\gamma_{\mathrm{c}}$ - service factor; $\alpha_{1} ; \alpha_{2}$ - dimensionless factors; $c_{1}-$ cohesion of soils $[\mathrm{kPa}] ; \gamma_{1}-$ the volume weight $\left[\mathrm{kN} / \mathrm{m}^{3}\right] ; h_{1}-$ depth to top helice $[\mathrm{m}] ; A-$ area of the helice $\left[\mathrm{m}^{2}\right] ; f_{i}$ - design strength of soil on the shaft end $[\mathrm{kPa}] ; u$ - the perimeter of the helice screw pile shaft $[\mathrm{m}] ; h$ - the embedment depth of pile [m]; $d$ - diameter of the shaft [m] [2].

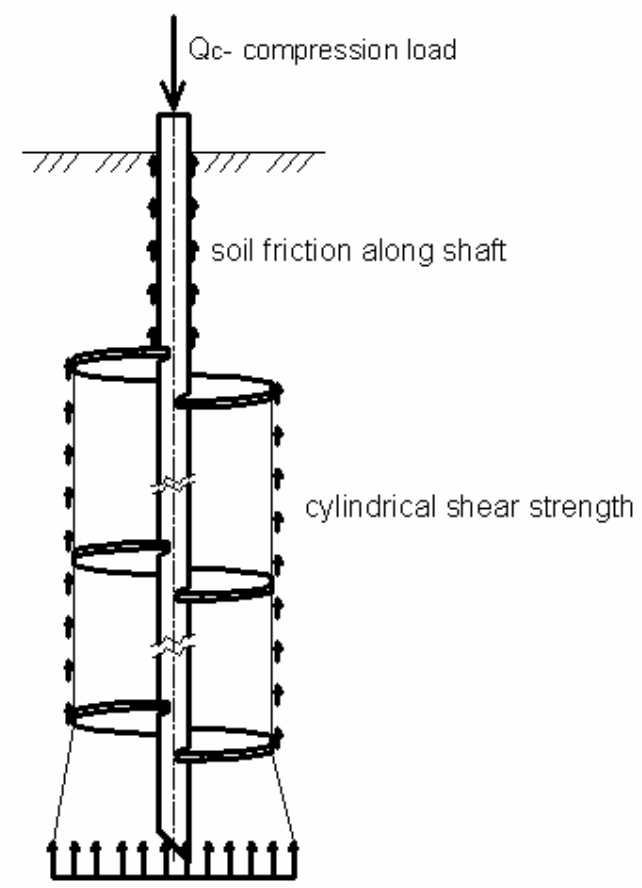

Figure 2. Screw pile scheme according to large capacity screw pile's method

\subsection{The ultimate compression capacity of the helical screw pile according to Canadian building engineer calculation method}

Methods for estimating pile ultimate capacities were proposed by. Narasimha Rao [6] for the design of screw piles in cohesive soils and. Mitsch and Clemence [5] for the design of screw piles in cohesionless soils. In the case of compressive loading, see Figure 2, the total failure resistance can be summarized as follows, see Equation (2):

$Q_{S P}=Q_{L}+Q_{G . P}+Q_{K}$

where $Q_{S P}-$ ultimate pile compression capacity [kN]; $Q_{L}$ - shearing resistance mobilized along the cylindrical failure surface $[\mathrm{kN}] ; Q_{G P}$ - bearing capacity of pile in compression $[\mathrm{kN}] ; Q_{K}$ - resistance developed along steel shaft $[\mathrm{kN}][6]$.

For a cohesive soil the ultimate compression capacity of the helical screw pile using a cylindrical shearing method, see Equation (3), (4), (5), (6), as proposed by Mooney and Narasimha [6] is:

$Q_{L}=S f \cdot\left(\Pi \cdot D \cdot L_{C}\right) \cdot C_{U}$

$Q_{G P}=A_{H} \cdot C_{U} \cdot N_{C}$

$Q_{K}=\Pi \cdot d \cdot H_{e f f} \cdot \alpha \cdot C_{U}$

$Q_{S P}=S f \cdot\left(\Pi \cdot D \cdot L_{C}\right) \cdot C_{U}+A_{H} \cdot C_{U} \cdot N_{C}+\Pi \cdot d \cdot H_{e f f} \cdot \alpha \cdot C_{U}$ 
For a cohesionless soil the ultimate compression capacity of the helical screw pile using a cylindrical shearing method (Where H/D $\geq 5$ ) as proposed by Mitsch and Clemence [5] is, see Equations (4), (7), (8), (9), (10):

$$
\begin{aligned}
& Q_{L}=\frac{1}{2} \cdot \Pi \cdot D_{a} \cdot \gamma^{\prime} \cdot\left(H_{3}^{2}-H_{1}^{2}\right) \cdot K_{s} \cdot \tan \varphi \\
& Q_{G P}=\gamma^{\prime} \cdot H \cdot A_{H} \cdot N_{q} \\
& Q_{K}=\frac{1}{2} \cdot P_{S} \cdot H_{e f f}^{2} \cdot \gamma^{\prime} \cdot K_{S} \cdot \tan \varphi \\
& Q_{S P}=\gamma^{\prime} \cdot H \cdot A_{H} \cdot N_{q}+\frac{1}{2} \cdot \Pi \cdot D_{a} \cdot \gamma^{\prime} \cdot\left(H_{3}^{2}-H_{1}^{2}\right) \cdot K_{s} \cdot \tan \varphi+\frac{1}{2} \cdot P_{S} \cdot H_{e f f}^{2} \cdot \gamma^{\prime} \cdot K_{S} \cdot \tan \varphi
\end{aligned}
$$

where $Q_{S P}-$ ultimate pile compression capacity [kN]; $D$ - diameter of helix [m]; $D_{a}$ - average helix diameter [m]; $L_{c}-$ is the distance between top and bottom helical plates $[\mathrm{m}] ; C_{u}$ - undrained shear strength of soil $[\mathrm{kPa}] ; A_{H}-$ area of the bottom helix $\left[\mathrm{m}^{2}\right] ; N_{c} ; N_{q}-$ dimensionless bearing capacity factors; $d$ - diameter of the shaft $[\mathrm{m}]$; $H_{\text {eff }}$ - effective length of pile [m]; $\alpha-$ adhesion factor; $S_{f}$ - spacing ratio factor; $\gamma^{\prime}-$ the volume weight $\left[\mathrm{kN} / \mathrm{m}^{3}\right] ; K_{s}$ - coefficient of lateral earth pressure in compression loading; $\varphi$ - soil angle of internal friction in degrees; $H$ - the embedment depth of pile [m]; $D_{1}$ - diameter of top helix [m]; $H_{1}-$ depth to top helix [m]; $H_{3}-$ depth to bottom helix $[\mathrm{m}] ; P_{s}$ - the perimeter of the screw pile shaft $[\mathrm{m}][5]$.

\subsection{The ultimate compression capacity of the helical screw pile according to USA „A.B.CHANCE” company method}

This theory suggests that the capacity of a foundation anchor is equal to the sum of the capacities of individual helices, see Figure 3 . The helix capacity is determined by calculating the unit bearing capacity of the soil and applying it to the individual helix areas. Friction along the central shaft is not used in determining ultimate capacity. A necessary condition for this method to work is that the helices be spaced far enough apart to avoid overlapping of their stress zones [4]. The calculation apply different parameters of soil - cohesive factor of soils, the volume weight, pressure of soil, as well as area of the helix and depth to helix.

Ultimate theoretical capacity of a multi-helix foundation equals the sum of all individual helix capacities, see Equation (11). To determine the theoretical bearing capacity of each individual helix, use Equation (12) [2].

$$
\begin{aligned}
& Q_{t}=\sum Q_{h} \\
& Q_{t}=A_{h}\left(9 c+q N_{q}\right) \leq Q_{s}
\end{aligned}
$$

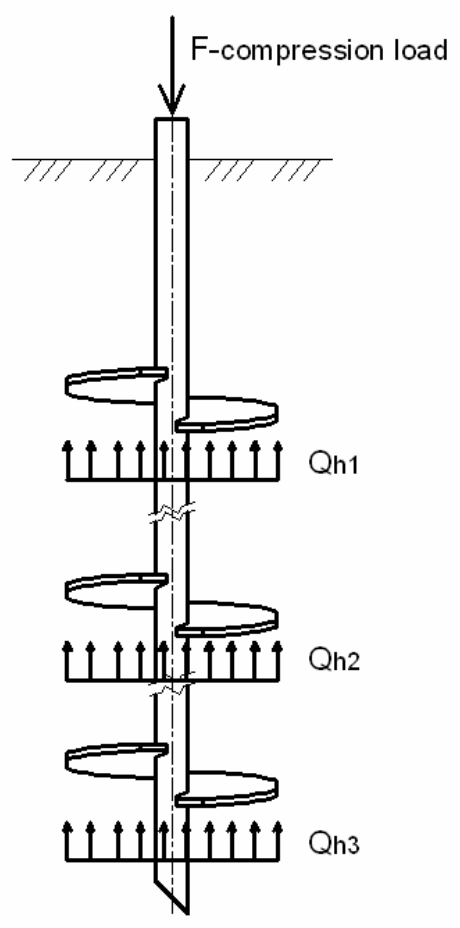

Figure 3. Screw pile scheme according to USA "A.B.CHANCE" company's method 
where $Q_{t}-$ total multi-helix anchor capacity [kN]; $Q_{h}$ - individual helix bearing capacity [kN]; $A_{h}-$ projected helix area $\left[\mathrm{m}^{2}\right] ; c$ - soil cohesion; $q$ - effective overburden pressure $\left[\mathrm{kN} / \mathrm{m}^{2}\right]$, use Equation (13); $N_{q}$ - bearing capacity factor; $Q_{s}-$ upper limit determined by helix strength $[\mathrm{kN}]$;

$q=\gamma \cdot d$

where $q$ - effective overburden pressure $\left[\mathrm{kN} / \mathrm{m}^{2}\right] ; \gamma$ - effective unit weight of soil $\left[\mathrm{kN} / \mathrm{m}^{3}\right] ; d$ - depth to helix [m] [4].

\section{BEHAVIOUR ANALYSYS IN DIFFERENT SOILS}

The capacities of screw pile's are obtained by methodic of USA "A.B.CHANCE" company. The screw pile is examined in four different soils with capacitive plates in amount from one till six. Soils geological properties description is given in table 1.

Table 1. Soil characteristics

\begin{tabular}{|c|c|c|c|c|c|}
\hline Nr. & $\begin{array}{c}\text { Porosity } \\
\text { ratio } \\
\text { factor } \mathbf{e}_{\mathbf{n}}\end{array}$ & $\begin{array}{c}\text { Volume weight } \\
\boldsymbol{\rho}_{\mathbf{n}}, \mathbf{g} / \mathbf{c m}^{\mathbf{3}}\end{array}$ & $\begin{array}{c}\text { Soil angle of } \\
\text { internal friction, } \\
\text { degree } \boldsymbol{\varphi}^{\circ}\end{array}$ & $\begin{array}{c}\text { Cohesive of soils } \\
\mathbf{c}, \mathbf{k P a}\end{array}$ & $\begin{array}{c}\text { Module of } \\
\text { elasticity } \mathbf{E}, \mathbf{M P a},\end{array}$ \\
\hline 1. & $0.70-0.76$ & 1.67 & 24 & $0-1$ & 10 \\
\hline 2. & 0.90 & 1.75 & 15 & 15 & 7 \\
\hline 3. & 0.35 & 2.25 & 37 & 0 & $>21$ \\
\hline 4. & 0.90 & 2.0 & 32 & 5 & $>10$ \\
\hline
\end{tabular}

Soil No 1 - fine, light grey with shivers of seashells, plants and wood, imbued with water, mealy, average compact sand. No 2 - flowing, plastic, muddy, peaty, brown grey, wet sand-clay. No 3 hard, red brown, brown grey sandy loam (moren) with grit pebble. No 4 - hard loam, semi hard clay, grey green, dolomite macadam on top, with pieces of gypsum.

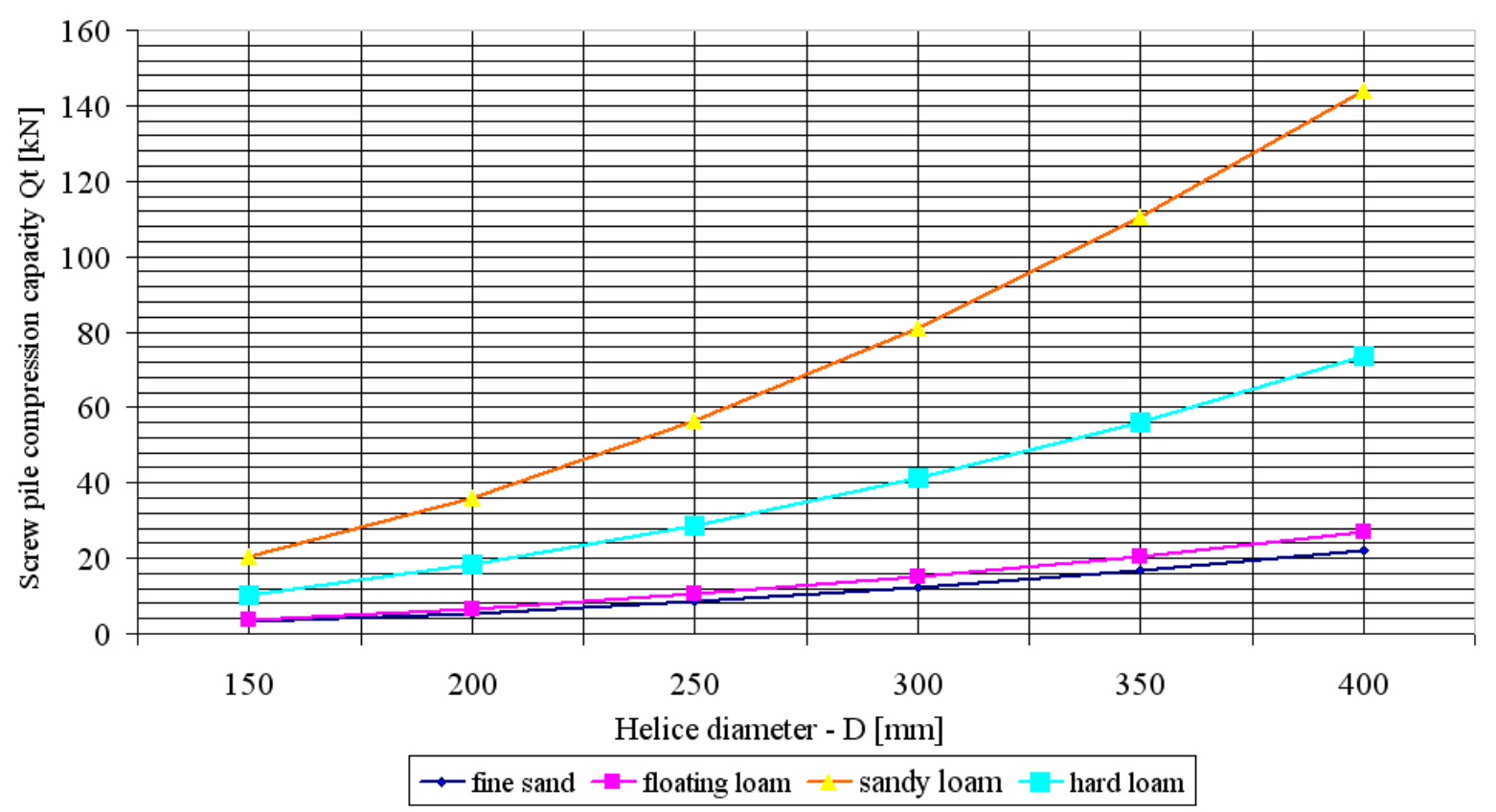

Figure 4. The compression capacity of screw pile in different soils depending on variety of plates diameter $D$, if all sizes of plates are into $150 \mathrm{~cm}$ depth from the top layer of soil. 
There has been observed how helical screw pile compression capacity changes into one type soils, while changing the helice's diameter. Observed screw pile is with one capacitive plate. All the plates are screwed within minimal allowable depth - according to USA “A.B.CHANCE" company's projecting guidelines it is five capacitive piles depth or not less than 1.5 meters.

To sum up all the results, see Figure 4, we can see that the amount of plates' diameter is essential influencing the capacity of screw pile. Establish that then larger the diameter, then higher the capacity, but not in all soils at the same matter. For example, let's compare $400 \mathrm{~mm}$ diameter plate in all four soils. The highest numbers of capacity is in soil No 3, then soil No 4, and then the rest - soil No 2 and No 1 the capacity is very similar. The difference in results between best and worst numbers of capacity in different soils is 6.5 times. Therefore there is no possible way how to determine the price of the screw pile capacity, because according to geometry - identical screw piles in different soils have different capacity [7].

Also there has been examined how screw piles compression capacity is influenced by the depth of screwing. Screw pile is screwed in starting with the minimal deposit depth - until 2 meter depth. The minimal depth of deposit is five diameters of plate, which is $5 \times 0.15 \mathrm{~m}=0.75 \mathrm{~m}$. In all depths the least possible capacitive plate is examined $-150 \mathrm{~mm}$.

As the result, the linear correlation is observed into all examined types of soil. Increasing the screwed depth, the higher capacity of screw pile will be obtained. The highest values of capacity in all depths are in soil No 3, then soul No 4 and only then soil No 2 and No 1 where capacity is similar. For example, if we examine capacity of screw pile in soil No 3 , when plate is screwed in $0.75 \mathrm{~m}$ depth and also when this depth is two time bigger $-1.5 \mathrm{~m}$. The difference of capacity is two times, the same as difference of depths. In other types of soils there is similar result correlation. Therefore, capacity of plate enlarges in direct ratio with the same amount as the depth of screwing enlarges which means that when you compress screw pile with two plates of the same size, the plate that is on the bottom will carry on more than the top one.

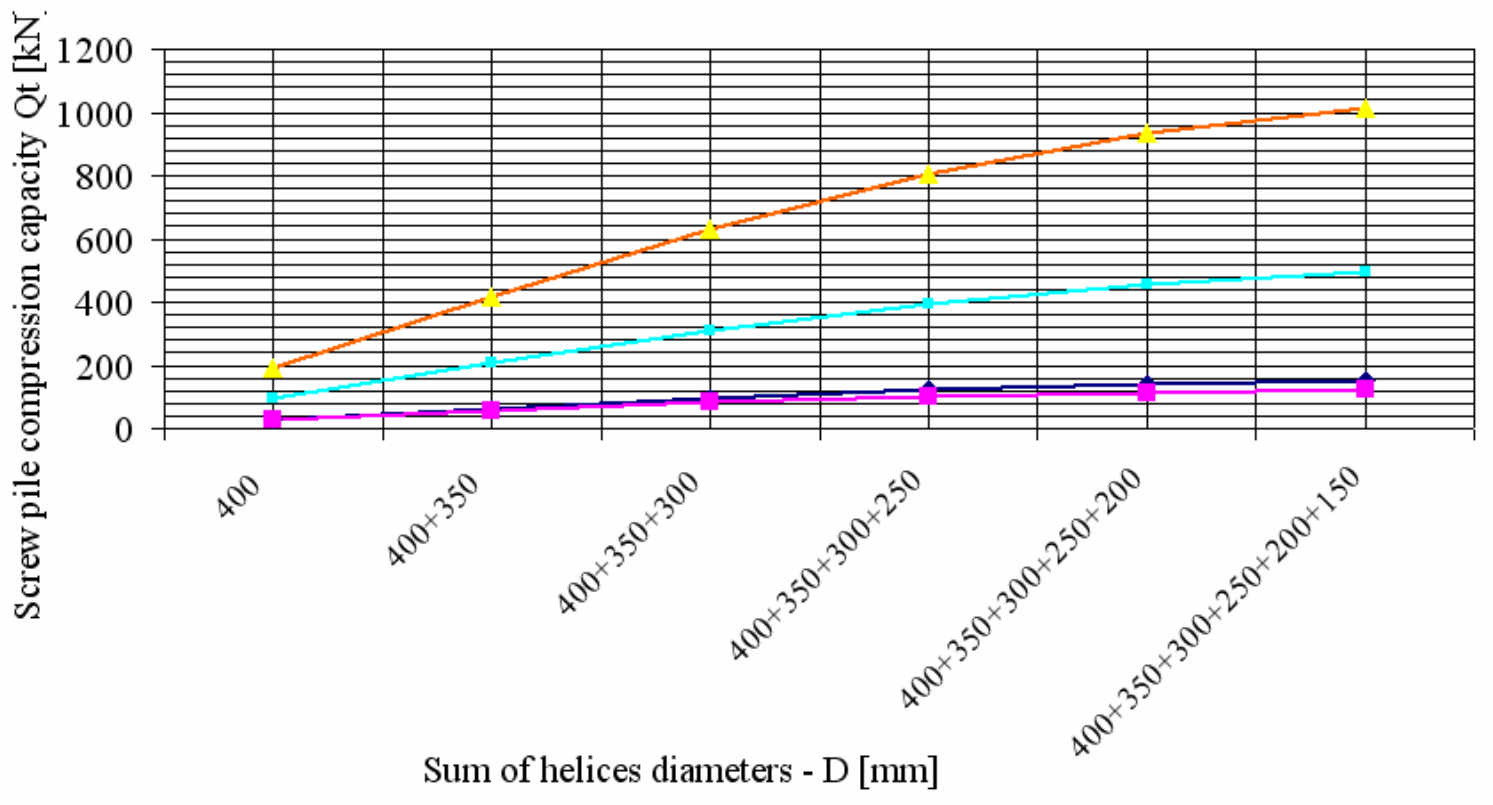

$\leftarrow$ fine sand $\rightarrow-$ floating loam -- sandy loam $\rightarrow-$ hard loam

Figure 5. Screw pile compression capacity with several helices

The amount of capacitive plates on screw pile influences its capacity in compression. There is limited screw pile capacity with one till six plates in soils mentioned above. The result, see Figure 5, shows that the highest numbers of capacity with different amount of plates are in soils No 3 . The maximal number of plates that has been examined is six [7]. 
It has been established that amount of plates and diameters for two screw piles can be extremely varied, but give similar results. So it is vital to find economically the most suitable and rational type of helical screw pile for each and every case individually, because the prime cost of screw pile depends on the total length of screw pile and the amount of capacitive plates [7].

\section{BEHAVIOUR OF SCREW PILE MODELED BY FINITE ELEMENT METHOD}

In Latvian building code LBN 214-03 "Geotechnics. The basics and foundations of piles" paragraph 33 there is defined that basements and foundations of piles with calculation examine for two limit states: inspection of capacity (the first limit state) and possible deformation and moving inspection (the second limit state). In practical work it has been observed that the second limit state often is the determinative.

As none of the methods mentioned above, including Latvian building code LBN 214-03 does not describe deformation of screw pile as well as not giving any calculation or evaluation principles, the finite element calculation model is developed by computer software "Lira 9.2" with what there is a clue of deformations of screw piles plates in different loading, in different soils as well as there is examined the character of screw pile deformation with specified pressure. The plasticity of soil in these calculations was not taken into account. In this calculation model it is possible to model soils in the depth what is necessary and to make layers of soils according to geology - within properties and depth. To make it easier for calculations, there has been developed homogeneous soil layer in total depth of screw pile.

By software "Lira 9.2" the screw pile is examined in four different soils - fine sand, floating loam, sandy loam, hard loam, as well as the behavior of screw pile with one and two capacitive plates. The type of load is compression. There are given two examples with one and two capacitive plates on the screw piles shaft.

\subsection{The example of calculation of helical screw pile with one capacitive plate}

There is a helical screw pile model with one capacitive plate which diameter is $800 \mathrm{~mm}$ and thickness is $10 \mathrm{~mm}$. The depth of plates deposit $-2 \mathrm{~m}$ from the top layer of soil. The soil in which the screw pile is calculated - floating loam $\left(\gamma=17.5 \mathrm{kN} / \mathrm{m}^{3}, \varphi=15^{\circ}\right)$, see Table 1. With the USA "A.B.CHANCE" company method there has been established the capacity of screw pile in such soil $-121 \mathrm{kN}$. The concentrated compression load is imposed to this screw pile $-\mathrm{F}=100 \mathrm{kN}$ with the soils deadweight. The calculation process stages - 1;2;3, see Figure 6, are gained from "Lira 9.2.", there is shown how soil shear moves during the loading.

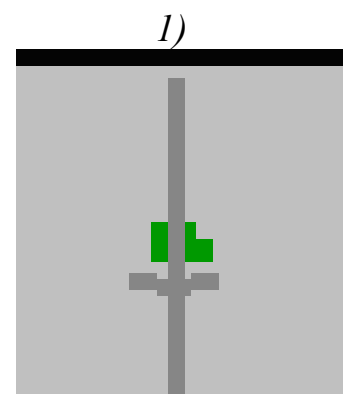

2)

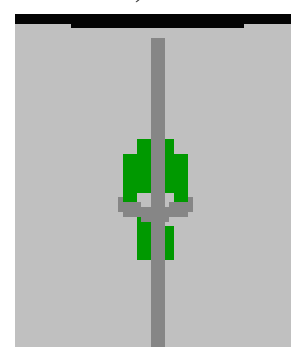

3)

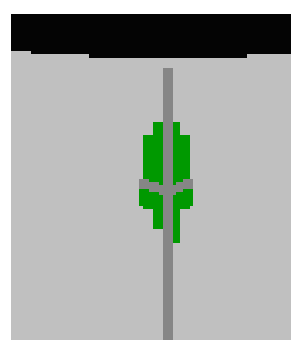

Figure 6. Soils massive shear strain development during the loading process

In Figure 7 there is shown how soil is deforming along with the screw pile and how far soil is influenced with such a concentrated load, which is added to screw pile. 

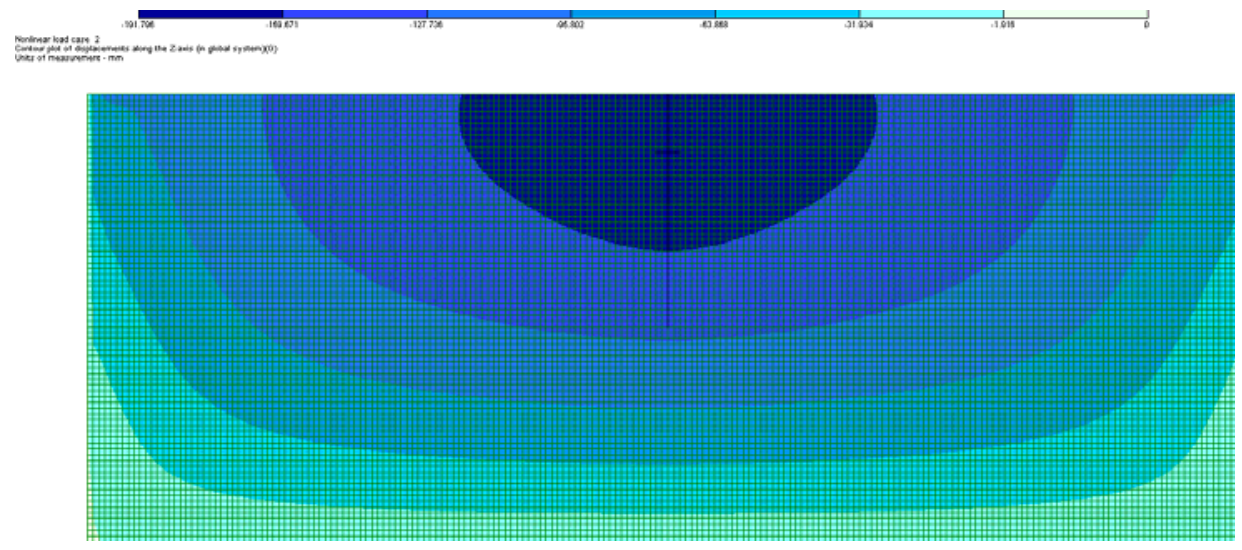

Figure 7. Deformations of the soils massive with helical screw pile into vertical direction

In Figure 8 there is shown the stresses Nz. Under the capacitive plate the stresses of soil are higher than above the plate.

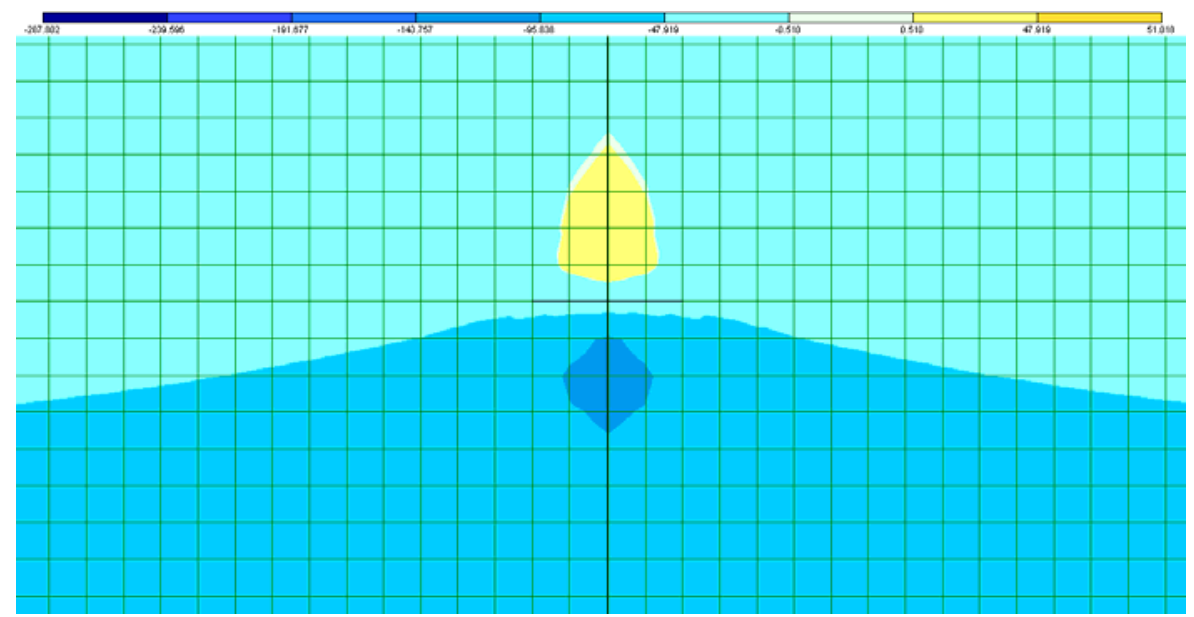

Figure 8. Soil stresses Nz around helice

\subsection{The example of calculation of screw pile with two capacitive plates}

There is created a screw pile model with two capacitive plates. For better comparison of calculation both capacitive plates' diameters and the thickness are accepted $800 \mathrm{~mm}$ and $10 \mathrm{~mm}$ respectively. The depth of the first plate deposit $-2 \mathrm{~m}$ deep from the soil's top, the second capacitive plate's distance from the first one - three diameters form plates below $-2.4 \mathrm{~m}$. The soil in which the screw pile is calculated - floating loam $\left(\gamma=17.5 \mathrm{kN} / \mathrm{m}^{3}, \varphi=15^{\circ}\right)$, see Table 1. With the USA "A.B.CHANCE" company method there has been established the capacity of screw pile in such soil $-304 \mathrm{kN}$. The concentrated compression load is added to this screw pile $-\mathrm{F}=250 \mathrm{kN}$ with the soils deadweight.

The calculation process stages $-1 ; 2 ; 3$, see Figure 9, are gained from program "Lira 9.2.". In this picture there is shown how soil shear moves during the loading. 
1)

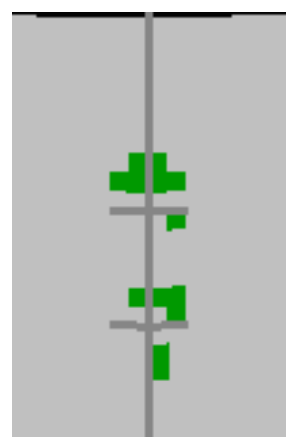

2)

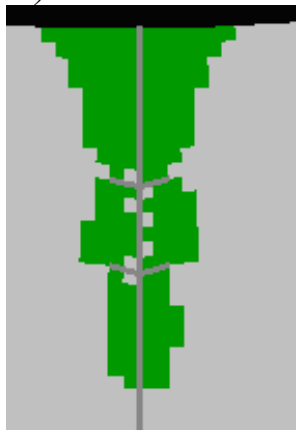

3)

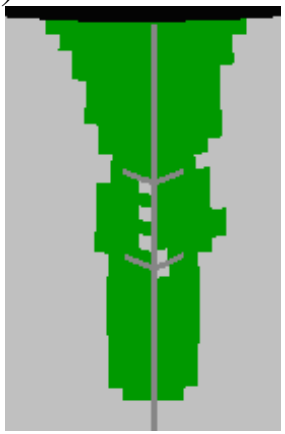

Figure 9. Soils massive shear strain development during the loading process

In Figure 10 shown soil stresses Nz. The larger stresses are underneath the capacitive plates. The maximal stresses are under the lowest plate, therefore the least stresses are above the higher placed plate.

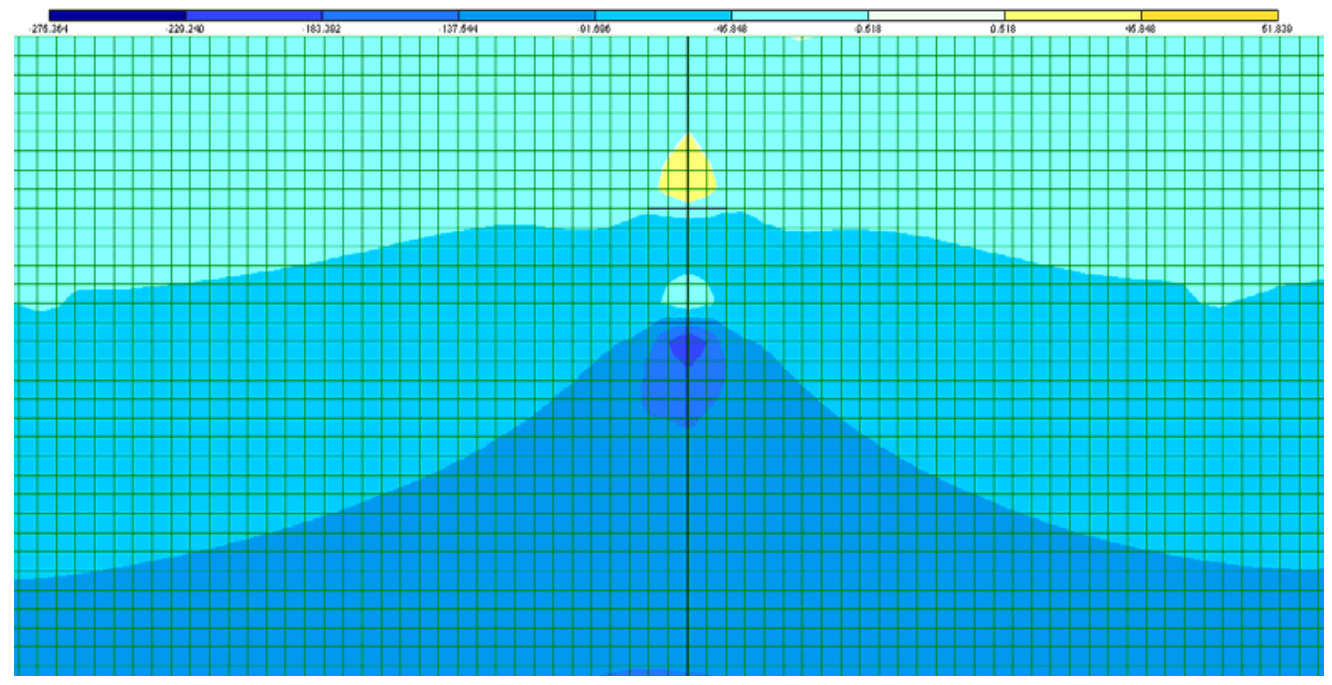

Figure 10. Soil stresses around helices

Analyzing the picture 10 more carefully, can see that the software "Lira 9.2" every plate assume as separate element and that is according to USA "A.B.CHANCE" company's established methodic of screw pile behaviour and calculation.

The obtained results are logical: in hard soils screw pile deforms less and more uniform and screw pile plate's deformation comparing to all deformations of screw pile is small, but in weaker soils this deformation enlarges [7]. The limited values of screw piles deformations depend of the type of the building, what is established according to project, client or according to LBN 207-01 "Geotechnics. The basics and foundations of piles", annex 4 [2]. The started work with finite element calculation models could be as a basis for further researches.

\section{CONCLUSIONS}

There have been examined three methods of helical piles capacity. For LBN 214-03 method the incompleteness has been determined: there is no information how to proceed if calculations need to be performed for screw pile with two or more plates, also there no references how screw piles plates must be placed on the handle constructively. 
There has been analyzed helical screw pile in compression in four different soils with different amount of capacitive plates.

By computer software "Lira 9.2" the finite element model of soil together with screw pile is developed, that helps to get information about screw pile and soil's behaviour in compression. In the same way it is possible to see plates and soils deformations under this load, as well as stresses what appear in soils underneath the plates. As a result, the dependences are gained which show:

- The capacity of helical screw piles influences the size of capacitive plate diameter, but not in all soils at the same matter. After the results, the difference between various soils can be up to 6 times.

- According to geometry identical screw piles in different soils will have different capacity, therefore it is impossible to define the price of screw pile capacity.

- According to results the conclusion can be made that if the depth of the screwed plate is enlarged, capacity enlarges in direct ratio.

- Two screw piles plates amount and diameter can differ, but gives similar capacity. To take for consideration that prime cost of screw piles depends on its total length and amount of capacitive plates, it is important to find the best solution of screw piles from economical as well as rational point of view.

- The developed calculation model in computer software "LIRA 9.2" each plate considers as separate capacitive element, what is according to USA "A.B.CHANCE" company's established calculation method of screw piles capacity. From the results it is conducted that plate which is lower takes more pressure than that which is higher, what matches the results of rationalization researches.

- The development of calculation method for deformations and verification for finite elements calculation model and modification for soils plasticity evaluation - it is a direction for further researches.

\section{REFERENCES}

1. Laivinsh E., Rosihins J. Soil Mechanics, foundations and basics for industrial and civil constructions. Zvaigzne, Riga, 1970 (in Latvian).

2. Latvian building code LBN 214-03 Geotechnics. The basics and foundations of piles. Riga, 2003.

3. Chance Civil Construction // In: http://www.abchance.com, (06.05.2009).

4. CHANCE $^{\circledR}$ Civil Construction Helical Systems CC Catalogue // CD - Centralis, Missouri, USA, 2003.

5. Mitsch, M.P., and Clemence, S.P. The Uplift Capacity of Helix Anchors in Sand. Uplift Behavior of Anchor Foundations in Soil // Proceedings of ASCE.- New York, 1985, p. $26-47$.

6. Narasimha Rao, S., Prasad, Y. V. S. N., and Shetty, M.D. The behavior of model screw piles in cohesive soils. // Soils and Foundations Vol.31,No.2, 1991, p.35-50

7. Sprince A. Determination of rational geometrical parameters of screw piles in different soils. Masters thesis. Department of Structural Engineering, Institute of Structural Engineering and Reconstruction, Riga Technical University, Riga: 2009. - p.98. (in Latvian).

8. СНиП 2.02-03-85 Pile foundations. Moscow, 1986 (in Russian).

Andina Sprince, M.sc.ing.

Institute of Materials and Structures, Riga Technical University

Azenes St 16/20, Riga LV-1048, Latvia

Phone: +371 7089248, E-mail: andina.sprince@rtu.lv

Leonids Pakrastinsh, assoc.prof, Dr.sc.ing.

Institute of Structural Engineering and Reconstruction, Riga Technical University

Azenes St 16/20, Riga LV-1048, Latvia

Phone: 371 7089145, E-mail: leonids.pakrastins@rtu.lv 


\section{Sprince A., Pakrastiṇš L. Skrūvpāḷa darbības analīze dažādās gruntīs}

Izpētìta skrūvpālu pamatu sistēma un to darbības princips spiedē. Apskatīts slodzes nodošanas mehānisms uz grunti. Apskatītas trīs aprēķina metodes: Latvijas būvnormatīvs LBN 214-03 (СНuП 2.02-03-85), ASV kompānijas "CHANCE" un Kanādas büvinženieru izstrādātā lielas nestspējas skrūvpālu aprēķinu metodes, kas ir paredzētas skrūvpā̄lu nestspējas aprēķiniem. Veikts metožu salīdzinājums. Izklāstīti skrūupā̄lu pamatu izveidošanas principi, izvērtētas to priekšrocības un trūkumi. Skrūvpālis analizēts četrās dažādās gruntīs -

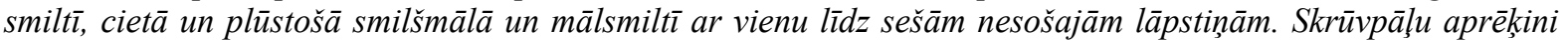
spiedè veikti pēc ASV kompānijas “A.B.CHANCE” aprēķinu metodikas. Izvērtēti nespēju ietekmējošie faktori. Skrūvpālu darbības analīzes laika rastas sakarības, kuras var tikt izmantotas nosakot ekonomiski izdevīgāko un racionālāko skrūvpāli. Tà kā neviena no aprēķinu metodēm nenosaka skrūvpāạlu deformācijas noteikšanas un izvērtēšanas principus, izveidots galīgo elementu aprēķina modelis datorprogrammā „Lira 9.2”. Ar tā palīdzību apskatìta skrūvpā̄la un grunts darbība dažādās gruntīs pie noteikta slodžu lieluma ar vienu un divām nesošajām lāpstinnām. Tāpat aprēķinātas skrūvpālu deformācijas un spriegumi grunts masīvā. Pārvietojumu aprēķināšanas metodikas izstrādāšana, un galīgo elementu aprēknina model̦a verifikāaija un modifikācija grunts plastiskās darbības ievērtēšanai - ir virziens tālākiem pētījumiem.

\section{Sprince A., Pakrastinsh L. Helical pile behaviour analysis in different soils}

There has been explored the system of helical piles and its behaviour in compression. There have been examined principles of loads transmission mechanics on soil. There have been examined three calculation methods: Latvian building code LBN 214-03 "Geotechnics. The basics and foundations of piles" (CHuП 2.0203-85), "A.B.CHANCE" company calculation method and Canadian building engineer developed large capacity screw piles calculation methods which are provided for determination of helical pile capacity. There has been done the comparison of methods. There has been described the formation principles of screw piles basements and examined its advantages and disadvantages. There has been analyzed helical screw pile in compression in four different soils- fine sand, floating loam, sandy loam and hard loam with different amount of capacitive plates. The capacity of screw pile is obtained by methodic of USA "A.B.CHANCE" company. There have been evaluated factors, which cost incapability. During the analysis of screw piles activity there have been found some correlations which can be used to determine the most useful screw pile in terms of economics and rationalization. As none of the methods mentioned above does not examine deformation of screw pile as well as not giving any calculation or evaluation principles, the calculation finite element model is developed by computer software "Lira 9.2". Within its help there has been observed the interaction between screw pile and soil in different soils with specified loads with one or two capacitive plates. Also there have been calculated the deformations and stresses of screw piles in the massif of soil. The development of calculation method for deformation and verification for calculation model of finite elements and modification to take into account soils plasticity - it is a direction for further researches.

\section{Спринце А., Пакрастиньш Л. Анализ работы винтовых свай в различных грунтовых условиях.}

Исследована система фундаментов на основе винтовых свай, а также принцип их работы на сжатие. Проанализирован механизм передачи нагрузки на грунт. Рассмотрены три методики расчёта: на основе Латвийского строительного стандарта LBN 214-03 (СНиП 2.02-03-85), компании "А.В.СНАNCE" (США) и методики канадских строительных инженеров для расчета винтовых свай большой несущей способности. Произведено сравнение вышеупомянутых методик. Изложены основные приниипы сооружения фундаментов на винтовых сваях, а также оценены их позитивные и негативные особенности. Работа винтовых свай проанализирована для четырех типов грунтов - песчаного, плотного и зыбкого суглинков, а также супесчаного с количеством несущих лопастей сваи от одной до шести. Расчеты выполнялись на основании методики компании “А.В.СНАNCE”. Оиенены основные факторы, влияющие на несущую способность отдельной сваи. При помощи расчетов получень зависимости, на основании которых возможно определить наиболее экономически выгодныии и раииональный вариант винтовых свай. Поскольку ни одна из рассмотренных методик не имеет принципов оченки и расчета деформачий, сформирована конечно-элементная модель на базе программного пакета «Лира 9.2». На основе вышеупомянутой модели рассмотрена совместная работа винтовой сваи и грунта при определенном уровне нагружения и при одной или двух несущих лопастях, $a$ также определены деформации и напряжения в массиве грунта. В качестве направлений дальнейших исследований обозначены разработка методики расчета осадки свай, а также верификация конечноэлементной модели и её модификаиия для учета пластической работы грунта. 